\title{
LIVING / TOTAL DISTRIBUTION OF BENTHONIC FORAMINFERA ON GRAND BANK, GRAND BANKS OF NEWFOUNDLAND
}

MILLER*, Ann A.L., Dept. of Geology, Geo. Washington University, Bell Hall, 2029 G St. N.W., Washington D.C., 20052, U.S.A. (mailing address: Marine G.E.O.S., 3824 Novalea Dr., Halifax, N.S., B3K 5K5, Canada)

The Grand Banks of Newfoundland consist of $160,000 \mathrm{~km}^{2}$ series of shallow banks, separated from one another and the Island of Newfoundland by deeper channels or enclosed basins. The largest and westernmost bank is Grand Bank. The predominant ocean current is a counterclockwise circular gyre. This pattern results from the influence of the Labrador Current and Gulf Stream current with tidal effects superimposed. Grand Bank experiences strong wave action because of the large number of intense storms which cross the area from southwest to north-northeast; these storms are particularily intense in winter.

Living / total benthonic foraminiferal studies have been completed on 171 samples (from 65 stations, collected on 3 scientific cruises) across Grand Bank. Samples were collected in May (cruise 87-014), June (cruise 89-006) and Sept. (cruise 94-021) to compare short term temporal variations; 2 subsamples per station (cruises 89-006 and 94-021) or 4 subsamples per station (cruise 87-014) were collected to look at within station variability. Living foraminfera were determined by staining with Sudan Black.

South of Hibernia faunas are predominantly calcareous. On northwest Grand Bank, north central Grand Bank and northeast Hibernia samples collected in June (2 samples per station) have low total numbers per sample and within station variability is low; and living / total percent occurrences of most species are similar (per sample). The fauna is dominated by agglutinated foraminfera, mostly (50-90\%) Eggerella advena; in water $>150 \mathrm{~m}$ deep Adercotyma glomerata, Reophax spp. and Veleroninoides spp. increase in number as the occurrence of $E$. advena decreases. On northwest Grand Bank the calcareous genera Buccella (B. spp.) is subdominant; on north central Grand Bank and at Hibernia Cibicidoides spp. (including Lobatula lobatalus) and Islandiella spp. are subdominant.

At the G.B.S. site at Hibernia, south central Grand Bank, Southeast Shoal and southeast of Hoyles Canyon, samples collected in May (4 / station) have very low to very high total numbers, within station variability is high and the living population not in equilibrium with the total assemblage. $\underline{C}$. reniforme is dominant and Criboelphidium spp. is subdominant both in the living population and total assemblage; Islandiella spp. is dominant in both components in some samples, and $\underline{\mathrm{L}}$. lobatalus subdominant in the total assemblages only. E. advena is consistently present at south central Grand Bank and $\underline{\mathrm{A}}$. angulosa at Southeast Shoal.

Generally, samples collected in June and Sept. have higher total numbers, lower within station variability and the living / total fractions are in equilibrium. Agglutinated foraminifera dominate where the Labrador Current is strongest; calcareous foraminifera where the Gulf Stream has greater influence. Total numbers are directly correlated to the strength of tidal and storm currents and circulation gyres.

Analysis of the surficial distribution of foraminifer on Grand Bank provides the ground truth for late glacial / post-glacial (core) and older Quaternary (borehole) deposit studies essential before the development of offshore petroleum resources at Hibernia, Terra Nova, and other sites on Grand Bank. 